\title{
回転弾性球の衝突時挙動に対する平面運動解析*
}

\author{
瞱道佳 明*1, 平田彰*2, 片岡真澄*3 \\ 高橋芳 弘 $^{* 3}$, 植 草昌彦*3, 兽我部 潔*1

\section{Planar Motion Analysis for a Rotating Elastic Ball in Collison} \\ Yoshiaki TERUMICHI*4, Akira HIRATA, Masumi KATAOKA, \\ Yoshihiro TAKAHASHI, Masahiko UEKUSA and Kiyoshi SOGABE \\ ${ }^{* 4}$ Department of Mechanical Engineering, Sophia University, \\ 7-1 Kioi-cho, Chiyoda-ku, Tokyo, 102-8554 Japan

\begin{abstract}
It is generally well known that the motion of rotating elastic body in collision is complex but interesting. This is due to the deformation of the local contact part, the friction force acting on the contact surface and so on. It is difficult, however, to observe the state of affairs in collision because of instantaneous phenomenon. In this paper, two types of model for the motion of the rotaing elastic ball in planar collision are proposed. One is a simple model which consists of two particles with spring and damper. Another one consists of distributed particles in circumference, spring and dampers. An experiment is also carried out to compare with numerical results and verify their validity, using a high speed camera. The simple model represents some characteristics of the motion. Numerical results using another model agreed with experimental ones both qualitatively and quantitatively.
\end{abstract}

Key Words: Mulyibody Dynamics, Unilateral Contact, Collision, Elasticity

\section{1. 緒 論}

2 物体の接触, 衝突系の運動解析を行う際, 精度良 い解析を実現するためには接触中の運動を的確に表現 するモデリングが必要となる. マルチボディダイナミ クスにおいてUnilateral Contacts と呼ばれるこの種 の問題には多くの関心が奇せられ，モデリング, 定式 化手法が検討されている. しかしながらその多くは剛 体の接触問題(1) (3)を扱ったものである.

一方, 特に物体が弾性に富みかつ回転を有する場合 には，その衝突，接触時挙動は複雑で，モデリングそ のものに物理的洞察を要することが多い.これは弾性 体の微小な局所的変形が挙動全体に大きな影響を与え るからである.

この種の問題に対しては, エネルギの保存を前提と した定式化 ${ }^{(4)}$, 殼要素を利用した離散的モデルの提 案などが行なわれ，また，フォークト要素を用いた弾 性体の接触時挙動に対応するモデルの提案 ${ }^{(5)(6)}$ も行な われているものの議論が十分なされたとはいえない.

そこで本報では，回転弾性球の平面内衝突時挙動を

* 原稿受付 2003 年 11 月 20 日。

*1 正員, 上智大学理工学部(-102-8554 東京都千代田区紀尾 井町 7-1).

*2 学生員. 上智大学大学院理工学研究科 [現：(株) 日本エアシ ステム].

*3 正員, 千葉工業大学工学部( 275-0016 習志野市津田沼 2 17-1).

E-mail : y-terumi@ sophia.ac.jp
例としてその衝突, 跳ね返り挙動を精度良く表すこと ができるモデリングについて検討する.

まず高速度カメラにより回転弾性球の衝突時挙動 を撮像し, 接触中の物体がどのような動的特徴を有し ているかを見極める. この結果を基に，2質量とフォ 一クト要素の結合で表した簡易モデル, 多質量とフォ 一クト要素で表現した多質点モデルを考え定式化を行 う. そして, 衝突時の挙動を支配する諸因子について 数值解析結果と実験結果を比較することによりモデル の妥当性を検討する.

上記検討は，タイヤやゴムローラなどに代表され る弾性に富む機械要素の接触・衝突問題において, 高 効率, 高精度を満たすモデリング, 定式化の指針を与 えることが期待される.特に，これらの機械要素自身 の運動を考慮する必要がある場合, 例えば自動車の急 制動，急旋回時などの過渡的な運動のシミュレーショ ン手法などに多くの知見を与えるものと考える.

\section{2. 実酫}

実験には，良く知られているスーパーボール （Wham-0 Corp. 登録商標, 弾性球と呼ぶ）を用いた. 本実験の主な目的は, 弾性球に種々の並進および 回転を伴う面内運動を与えた場合の衝突時挙動, すな 
わち球が床面に接触している短い時間内の重心位置と 接触面中心とのずれである水平方向伸縮、重心位置の 床面への接近量である垂直方向伸縮、球の外周の䇢所 により回転速度が異なることによる回転角度差である 回転方向伸絔等の局所変形を高速度力メラを用いて撮 影し，画像解析を施すことから解析することである。 撮影は $2.22 \times 10^{-4}(\mathrm{~s} / \mathrm{f})$ で衝突直前から衝突直後まで 行った。 その様子（1フレーム）を図 1 に示す。ここ で球の表面には 16 分割した放射線状のラインが引い てあり，種々の水平方向速度，垂直方向速度，回転速 度を与えて撮影を行い，1回の衝突につき多数枚の静 止画像を取り出した.

次に図 2 に示寸 7 点 $(A, C, D, E, F, L, R)$ の時刻 $t$ と $t+\Delta t$ における運動の変位増分から重心の水平方向速 度 $\dot{X}_{G}$, 垂直方向速度 $\dot{Y}_{G}$, 回転速度 $\phi$ を, また, 時 刻 $t$ の画像加水平方向伸縮 $u$, 垂直方向伸縮 $Y_{G}-r$, 回転方向伸縮 $\theta$ ，接触幅 $b$ を近似的に算出した. ただ ᄂ,

$G\left(X_{G}, Y_{G}\right)=\left(\left(X_{R}+X_{L}\right) / 2, Y_{R}=Y_{l}\right)$

$B\left(X_{B}, Y_{B}\right)=\left(\left(X_{C}+X_{A}\right) / 2,0\right)$

$\dot{X}_{i}=\left(X_{G}^{1-\Delta t}-X_{G}^{\prime}\right) / \Delta t$

$\dot{Y}_{G}=\left(Y_{G}^{\prime-\Delta t}-Y_{G}^{\prime}\right) / \Delta t$

$\dot{\phi}=\left\{\tan ^{-1}\left(\begin{array}{c}Y_{D}^{t+\Delta t}-Y_{G}^{i+\Delta t} \\ X_{D}^{t+\Delta t}-X_{G}^{t+\Delta t}\end{array}\right)-\tan ^{-1}\left(\begin{array}{c}Y_{D}^{\prime}-Y_{G}^{\prime} \\ X_{D}^{\prime}-X_{G}^{\prime}\end{array}\right)\right\} / \Delta t(1)$

$\theta=\left\{\tan ^{-1}\left(\frac{Y_{E}^{\prime+\Delta t}-Y_{G}^{\prime+\Delta t}}{X_{E}^{\prime+\Delta t}-X_{G}^{\prime+\Delta t}}\right)-\tan ^{-1}\left(\frac{Y_{E}^{\prime}-Y_{G}^{\prime}}{X_{E}^{\prime}-X_{G}^{\prime}}\right)\right\}$

$-22.5 \pi / 180$

$u=X_{i_{i}}-X_{B}$

$b=X_{C}-X_{A}$

である。本実験では，上述の放射線状のラインを図 2 のようにマークし回転方向伸縮の読み取りに用いてい る.ここで, $r$ は球の半径, 点 $G$ は重心点, 点 $R, L$ は重心点と水平位置にある両端の点, 点 $A, C$ は床と の接触部位の両端点, 点 $F, E$ はそれぞれ点 $A, L$ に 隣り合う左側分割線上の端の点である。また文字の右 肩の添え字は時刻を示し, $\Delta t=2.22 \times 10^{-4}(s)$ である. 実験に用いた試料（球および床面）を表 1 に示す。

実験より接触中には上記各伸縮の発生している様 子が確認された。 また得られた動画像からは, 接触中 に弾性球と床面との間に顕著な滑りが生じる挙動, 見 かけ上滑りを伴わずに転がる挙動, さらに図 3 に示す ようなよく知られた挙動, すなわち運動方向の逆転を 伴う衝突と跳ね返りを多数回繰り返す挙動など多様な 挙動が存在することが確認された。

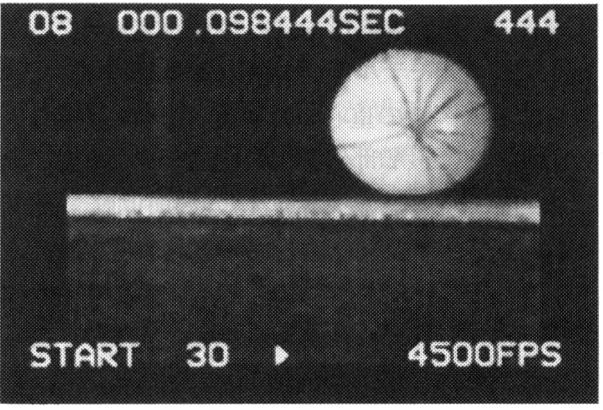

Fig.ure1 Photo of instantaneous ball motion in Collision

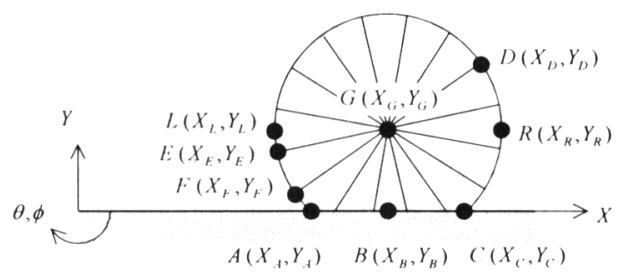

Figure2 Configuration in Collision

Table 1 Material property

\begin{tabular}{|c|c|c|}
\hline & Ball & Ground \\
\hline Material & Superball※ & Mild steel \\
\hline Mass (g) & 48.89 & - \\
\hline Radius (mm) & 23.3 & - \\
\hline Young's modulus (Mpa) & 3 & $2.07 \times 10^{5}$ \\
\hline Poisson's ratio & 0.46 & 0.28 \\
\hline Coefficient of friction & \multicolumn{2}{|c|}{0.9} \\
\hline
\end{tabular}

※Wham-O Corporation $の$ 登録商標

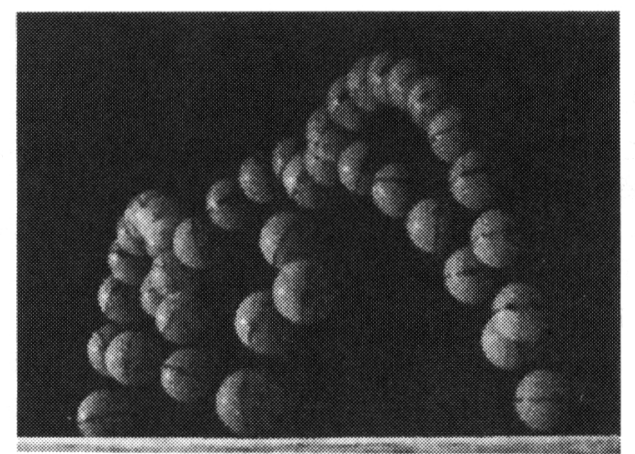

Figure.3 Photo of Bouncing Ball with Elasticity

3. モデリングと定式化

3.1 簡易モデル 実験で確認された回転弾性球の 運動を表現できる簡易モデルとして, 衝突中には接触 部分近傍に質量の偏りが発生すると考え, 球の質量 $m$ を重心と接触面中心に配分した 2 質点と, 水平, 
垂直および回転方向に作用する 3 つのフークト要素 からなる 2 次元モデルを提案する. すなわち図 4 に示 すように非衝突時の重心の位置 $G$ 点の衝突時の座標 を $G\left(X_{G}, Y_{G}\right)$, 接触部位の中心座標を $B\left(X_{B}, Y_{B}\right)$, 球 全体の回転角を $\phi$, 接触点近傍の局所回転角を $\psi$ と する. 回転角は時計回りを正とする.ささらに摩擦力を 考慮するためスライダを挿入した. なお接触の開始お よび終了は, $G$ 点の $Y_{G}$ が球の半径 $r$ と等しくなった ことで判定する. ここで, 球の形状変化分を $\Delta r$ とす るとき一般に $\Delta r / r$ は十分小さく, また接触点付近で の変形が支配的であり球全体では半径を一定とした球 を想定できることなどから，本報では運動への影響は 無視し得るものとして扱う.

垂直方向の剛性 $k_{n}$ は, ヘルツの接触理論を動的問 題に近似的に拡張し，

$$
k_{n}=\sqrt[3]{\frac{16 r N}{9 e^{2}}}
$$

として時々刻々更新する.ここで $N, e$ は

$$
\begin{gathered}
N=c_{n} \dot{Y}_{G}+k_{n}\left(Y_{G}-r\right) \\
e=\frac{1-v_{i}^{2}}{E_{i}}+\frac{1-v_{w}^{2}}{E_{w}}
\end{gathered}
$$

であり， $N$ は垂直方向に作用する力, $v$ はポアソン 比, $E$ は縦弾性俰数, また, 添え字 $n, s, \phi$ は垂直, 水平, 回転の各方向, $i$ は球, $w$ は床面を示す. また 剛性 $k_{5}, k_{\phi}$, 減衰 $c_{s}, c_{\phi}$ は, 䋛弾性俰数之横弾性係数 の比（ラメ定数） $\tau$ を用いて,

$$
\begin{aligned}
& k_{s}=k_{\phi}=k_{n} \cdot \tau \\
& c_{s}=c_{\phi}=c_{n} \sqrt{\tau} \\
& \tau=\frac{3}{2\left(1+v_{i}\right)}
\end{aligned}
$$

とした(7). ただし, $c_{n}=2 \varsigma \sqrt{m k_{n}}(\varsigma=0.2)$ とした. ここで各剛性, 各減衰は垂直方向力 $N$ の関数であり 接触中に時々刻々変化することになる.

3.2 简易モデルによる定式化接触中の球の運動は 「転がり」と「すべり」という2つに大別できる.

(i )転がり発生時の運動方程式:

$$
\begin{aligned}
& (1-w) m \ddot{X}_{G}=-c_{s}\left(\dot{X}_{G}-\dot{X}_{B}\right)-k_{s}\left(X_{G}-X_{B}\right) \mp f \\
& w m \ddot{X}_{B}=c_{s}\left(\dot{X}_{G}-\dot{X}_{B}\right)+k_{s}\left(X_{G}-X_{B}\right) \\
& I \ddot{\phi}=\left\{-c_{\phi} r(\dot{\phi}-\dot{\psi})-k_{\phi} r(\phi-\psi) \pm f\right\} \cdot r \\
& \ddot{X}_{G}=r \ddot{\phi} \\
& I \ddot{\psi}=\left\{c_{\phi} r(\dot{\phi}-\dot{\psi})+k_{\phi} r(\phi-\psi)\right\} \cdot r
\end{aligned}
$$

ここで $f$ は転動の拘束力であり, 式(5) (9)より決定 できる. また $f$ 符号は $\dot{X}_{G}>0$ のとき式(5)では負, 式(7)では正となり， $\dot{X}_{G}<0$ のときはこの逆となる. $w$ は質量の偏りの割合で,ここでは $w=0.05$ とした. な お，Iは非衝突時の慣性モーメントであるが，衝突時

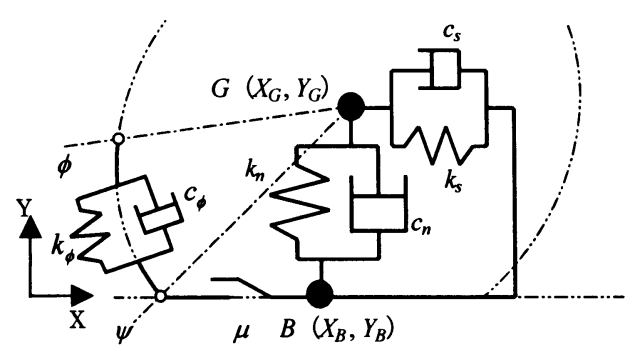

Figure 4 Analytical model (simple model)

における質量の分布は不明であることから簡単のため 式(7),(9)ではこれを用いた.

(ii )すべり発生時の運動方程式:

$$
\begin{aligned}
& (1-w) m \ddot{X}_{G}=-c_{s}\left(\dot{X}_{G}-\dot{X}_{B}\right)-k_{s}\left(X_{G}-X_{B}\right) \\
& w m \ddot{X}_{B}=c_{s}\left(\dot{X}_{G}-\dot{X}_{B}\right)+k_{s}\left(X_{G}-X_{B}\right) \pm \mu N \\
& I \ddot{\phi}=\left\{-c_{b} r(\dot{\phi}-\dot{\psi})-k_{\phi} r(\phi-\psi)\right\} \cdot r \\
& I \ddot{\psi}=\left\{c_{b} r(\dot{\phi}-\dot{\psi})+k_{b} r(\phi-\psi) \mp \mu N\right\} \cdot r
\end{aligned}
$$

ここで動摩擦力 $\mu N$ の符号は $\dot{X}_{B}-r \dot{\psi}>0$ のとき式 (11)では正, 式(13)では負となり $\dot{X}_{B}-r \dot{\phi}<0$ では逆 となる.

なお, すべりの状態から転がりの状態への移行は 重心の水平方向速度 $\dot{X}_{G}$ と球全体の回転速度 $r \dot{\phi}$ が等 しくなったときであり, 逆に転がりの状態からすべり の状態への移行は静止摩擦力 $\mu_{0} N$ より $f$ が大きくな ったときで, 静止摩擦力が小さいほど転がり状態から すべり状態へ移行しやすくなる.

次に垂直方向の運動方程式は転がりやすべりの挙動 とは関係なく

$$
\left.\begin{array}{l}
m \ddot{Y}_{G}=-c_{n} \dot{Y}_{G}-k_{n}\left(Y_{G}-r\right)-m g \\
Y_{C}=0
\end{array}\right\}
$$

で与えられるものとする. 以上どの状態の運動方程式 においても, 接触中における水平方向伸縮は $X_{G}-X_{B}$, 垂直方向伸縮は $Y_{G}-r$, 回転方向伸縮は $\psi$ - $\phi$ で表される. また, 接触幅 $b_{\text {HERTZ }}$ はへルツの接 触理論を用いることにし時間の関数とした.

$$
b_{H E R T Z}=2 \sqrt[3]{3 N \cdot e \cdot r / 4}
$$

なお「すべり」と「転がり」いずれの状態が発生 するかの判定は, 図5に示すフローチャートの判別に よった. ただし後述の数值解析では, $\dot{X}_{G}$ と $r \dot{\phi}$ とが 完全に一致することはほとんどないと考えられるため, その差 $\varepsilon$ が $1 \%$ 末満のとき, 相対速度が零と判断する ものとした. また簡単のため $\mu_{0}=\mu$ とした.

3.3 多質点モデル 本モデルは質量を重心の位置 $G$ 点と外周に多数個分布させ, それらをフォークト要 素で結んだもので, 前節で扱った各方向の伸縮といっ た局所変形に加えて, 外周質点の位置を把握すること 


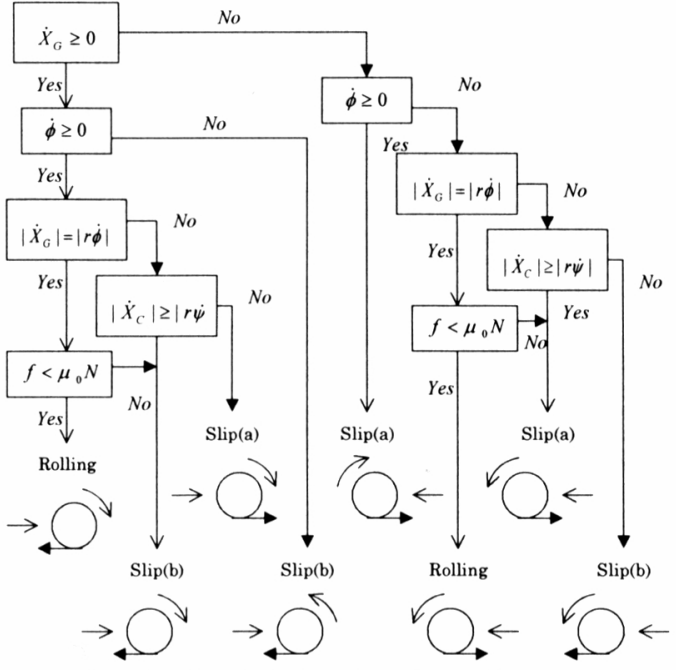

Figure 5 Flow chart to judge the contact condition

$A 2$

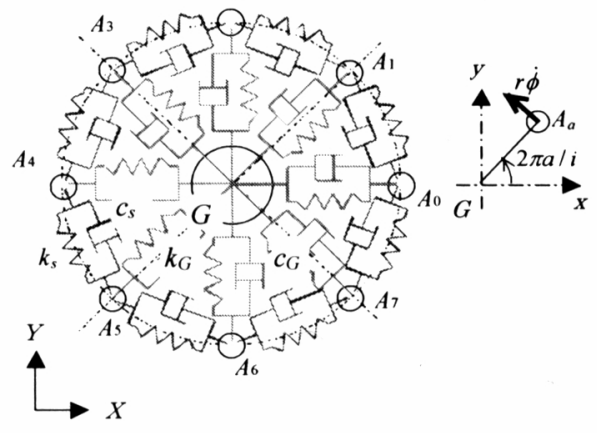

Figure 6 Analytical model (Multiple masses model, $i=8$ )

により球の変形状態を知ることができる.

図 6 に質点数 $i=8$ の場合のモデルを示す.ここで $G$ 点に配置した質点を $G\left(X_{G}, Y_{G}\right)$ （以下では質点 $G$ と呼ぶ），外周に配置された質点を $A_{a}\left(X_{a}, Y_{a}\right)$ （以 下では質点 $A_{a}$ と呼ぶ），質点 $G$ と質点 $A_{a}$ 間および外 周質点間のフォークト要素の岡性および減衰係数を 各々 $k_{G}, k_{s}, c_{G}, c_{s}$ とし, 添え字 $a$ は質点番号で $a=0,1,2, \cdots, i-1$ とする. ここで質点 $A_{a}$ は初期状態（接触 前)には質点 $G$ を基準として等角度で配置するものと すれば，その座標は，

$\left(X_{a}, Y_{a}\right)=\left(X_{G}+r \cos (2 \pi a / i), Y_{G}+r \sin (2 \pi a / i)\right)$ (16) と表され, また $A_{a}$ の衝突時初期速度は, 衝突した瞬 間の重心速度と回軾速度の接線方向分速度を加えて,

$\left(\dot{X}_{a}, \dot{Y}_{a}\right)=\left(\dot{X}_{G}-r \dot{\phi} \sin (2 \pi a / i), \dot{Y}_{G}+r \dot{\phi} \cos (2 \pi a / i)\right) \quad(17)$

次に外周質点の質量配分割合 $w_{a}$ は本モデルの慣性 モーメントを球の慣性モーメントに一致させることか
ら $w_{a}=0.4$ と決めた. 従って質点 $G, A_{a}$ の質量は $M_{G}=0.6 m, M_{a}=0.4 m / i$ とした. なお便宜上, 質 点 $G$ 回りの $i$ 個の剛性 $k_{G}$ 全てが並列に, また外周の $i$ 個の岡性 $k_{s}$ 全てが直列に慗がっているものと仮定し, これらの等価剛性にラメ定数 $\tau$ を導入して $k_{s}=i^{2} \tau k_{G}$ とした. また減衰係数 $c_{G}, c_{s}$ (わ はを減衰比として 以下のように表される.

$$
\begin{aligned}
& c_{G}=2 \zeta \sqrt{k_{G} m_{G} m_{0} /\left(m_{G}+m_{0}\right)} \\
& c_{s}=2 \zeta \sqrt{k_{s} m_{0}^{2} / 2 m_{0}}
\end{aligned}
$$

3.4 多質点モデルによる定式化 まず質点 $G$ の運 動方程式は, 質点 $G, A_{a}$ 間のフォークト要素による 力を $P_{a}$ とすれば

$$
\begin{aligned}
M_{G} \ddot{X}_{G} & =\sum_{a=0}^{i-1} P_{a} \cos \theta_{a} \\
M_{G} \ddot{Y}_{G} & =-M_{G} g+\sum_{a=0}^{i-1} P_{a} \sin \theta_{a}
\end{aligned}
$$

ここで質点 $G$ と $A_{a}$ 間の距離を $r_{a}$, これら 2 質点を結 ぶ方向の速度を各々 $v_{G}, v_{a}$ とすると, $P_{a}, v_{G}, v_{a}$ は以下のようになる.

$$
\begin{aligned}
& P_{a}=c_{G}\left(v_{a}-v_{G}\right)+k_{G}\left(r_{a}-r\right) \\
& v_{G}=\dot{X}_{G} \cos \theta_{a}+\dot{Y}_{G} \sin \theta_{a} \\
& v_{a}=\dot{X}_{a} \cos \theta_{a}+\dot{Y}_{a} \sin \theta_{a}
\end{aligned}
$$

ただし，

$$
\begin{aligned}
& \sin \theta_{a}=\frac{Y_{a}-Y_{G}}{r_{a}}, \quad \cos \theta_{a}=\frac{X_{a}-X_{G}}{r_{a}}, \\
& r_{a}=\sqrt{\left(X_{a}-X_{G}\right)^{2}+\left(Y_{a}-Y_{G}\right)^{2}}
\end{aligned}
$$

である。

次に外周質点 $A_{a}$ が床面と非接触の場合, および接 触する場合についての運動方程式は以下のように導出 される。

( i )床面と非接触の場合

図 7 に示すように質点 $A_{a}$ と $A_{a+1}$ を結ぶ方向と水平 方向とのなす角を $\beta_{a}$, 質点 $A_{a}$ の速度 $V_{a}$ の水平方向 となす角を $\varphi_{a}$ とおくと, 質点 $A_{a}$ の質点 $A_{a+1}$ 方向の速 度 $w_{a}$ は

$$
\begin{aligned}
w_{a} & =V_{a} \cos \left(\beta_{a}-\varphi_{a}\right) \\
& =\dot{X}_{a} \cos \beta_{a}+\dot{Y}_{a} \sin \beta_{a}
\end{aligned}
$$

同様に $V_{a}$ の $A_{a-1}$ 方向の速度 $u_{a}$ は

$$
\begin{aligned}
u_{a} & =V_{a} \cos \left(\beta_{a-1}-\varphi_{a}\right) \\
& =\dot{X}_{a} \cos \beta_{a-1}+\dot{Y}_{a} \sin \beta_{a-1}
\end{aligned}
$$

質点 $A_{a+1}, A_{a}$ 間のフォークト要素による力 $Q_{a}$ は, この 2 質点間の距離を $d_{a}$ とすると

$$
Q_{a}=c_{s}\left(u_{a+1}-w_{a}\right)+k_{s}\left(d_{a}-d_{0}\right)
$$

ただし， $d_{0}$ は初期配置時における質点 $A_{a+1}, A_{a}$ 間の 距離で $d_{0}=2 r \sin (\pi / i), \sin \beta_{a}=\left(Y_{a+1}-Y_{a}\right) / d_{a}$, 
$\cos \beta_{a}=\left(X_{a+1}-X_{a}\right) / d_{a}, \quad d_{a}=\sqrt{\left(X_{a+1}-X_{a}\right)^{2}+\left(Y_{a+1}-Y_{a}\right)^{2}}$ である. したがって，非接触である場合の質点 $A_{a}$ に 関する運動方程式は,

$$
\begin{aligned}
& M_{a} \ddot{X}_{a}=Q_{a} \cos \beta_{a}-P_{a} \cos \theta_{a}-Q_{a-1} \cos \beta_{a-1} \\
& M_{a} \ddot{Y}_{a}=Q_{a} \sin \beta_{a}-P_{a} \sin \theta_{a}-Q_{a-1} \sin \beta_{a-1}-m g
\end{aligned}
$$
となる. このとき質点 $A_{a}$ は床面と接していないため 垂直抗力 $N_{a}$ は $N_{a}=0$ とする.

（ii）床面と接触する場合

床面と接触している状態, 寸なわち $Y_{a}<0$ の場合 は $Y_{a}=0$ とし, 式(27)を考慮することから

$$
N_{a}=-\left(Q_{a} \sin \beta_{a}-P_{a} \sin \theta_{a}-Q_{a-1} \sin \beta_{a-1}-m g\right)
$$

次に水平方向には摩擦力が作用するから

$M_{a} \ddot{X}_{a}=Q_{a} \cos \beta_{a}-P_{a} \cos \theta_{a}-Q_{a-1} \cos \beta_{a-1}-\operatorname{sign}(\dot{X}) \mu N_{a}(29)$ このとき, 接触幅 $b_{m}$ は接触している外周質点 $X_{a}$ の うちの最大値と最小值の差 $X_{\text {max }}-X_{\text {min }}$ とする.

なお，（i ）または（ii）のどちらの運動方程式を採 用するかの判別は, 全ての外周質点 $A_{a}$ について刻み 時間 $\Delta t$ ごとに行い, $Y_{a}>0$ かつ $N_{a} \leq 0$ であれば( i ), それ以外であれば（ii）とした.

\section{4. 数值解析結果と実酫結果との比較検討}

4.1 衛突中の挙動の比校 本節では衝突中の挙動 に対する検討を行う. 数值解析では, 弾性球が床面に 衝突する直前の垂直方向速度, 水平方向速度, 回転方 向速度の実験結果を初期条件とした. この条件を表 2(a)に, 実験と計算結果による局所変形の比較を図 8 , 9 に示す. ここで外周の質点数は $i=96, k_{G}=4.29$

$(\mathrm{kN} / \mathrm{m})$ とした. これらの值は, 球に自重による静 荷重を加えた場合のへルツの接触理論より求まる重心 の床への接近量および接触幅と本モデルで計算したそ れらの值がほぼ等しくなるような $i$ と $k_{G}$ の組み合わ せより決定した. このとき球の自重をへルツの式より 求めた接近量で割った值 $\left(K_{\text {HERIS }}=6.60 \mathrm{kN} / \mathrm{m}\right)$ を $k_{G}$ の目 安とした。運動方程式の解法にはルンゲクッタ法 (4 次)を用い，刻み時間は $\Delta t=1.0 \times 10^{-7}(\mathrm{~s})$ とした。

図 8(a)は衝突中の接触幅を示したもので, 横軸は 衝突開始後の時間である.簡易モデルによる接触幅は ヘルツの接触理論より近似的に求めたが, 実験值に比 べ衝突開始直後の值が大幅に異なっており, この付近 での適用には難しい面が伺えるものの接触中全体とし ては定性的に一致していることがわかる。一方, 多質 点型モデルでは定性的, 定量的に実験結果とほぼ一致 していることがわかる. また接触している時間は実験 結果に比べ簡易モデルでは短め, 多質点モデルでは長 めとなっているが，その差は両モデルともほぼ 10\%以
内に収まっていることもわかる.

一方，図 8(b)，(c)は水平方向伸縮，垂直方向伸縮 を重心の位置から求めたものである. 簡易モデル，多 質点型モデルによる両伸縮值は実験值と定性的に一致 しており，特に垂直方向伸縮は定量的にもよく一致す ることがわかる. 本結果における多質点モデルの水平 方向伸縮が連続的でない理由は，主に質点の配置数に よって接触面積が不連続に扱われることによる.

図 8(d)屾回転方向伸縮を示したものである.ここ で多質点モデルでは各外周質点間の伸樎量が異なるた め実験で測定した個所と同位固（外周質点 $A_{60}$ と $A_{66}$ ）で比較を行った. 多質点モデルでは定性的, 定 量的に実験結果の特徵を良く捉えているが，簡易モデ ルでは，定性的には似た傾向を示寸ものの，定量的に は大きな差が生じている。これは衝突時には形状が球 形ではなく弾性球には各所に法線方向伸縮が発生し回 転に影響するが，これを簡易モデルでは考虑できない ためと考えられる.

図 9は各方向の伸縮速度を示したものである．回転 弾性球の衝突時挙動における特徴の一つと考えられる 速度の正から負または負から正への移行が簡易，多質 点モデルとも表現できていることがわかる．特に垂直 方向速度は実験值と定性的，定量的にも良好な一致を

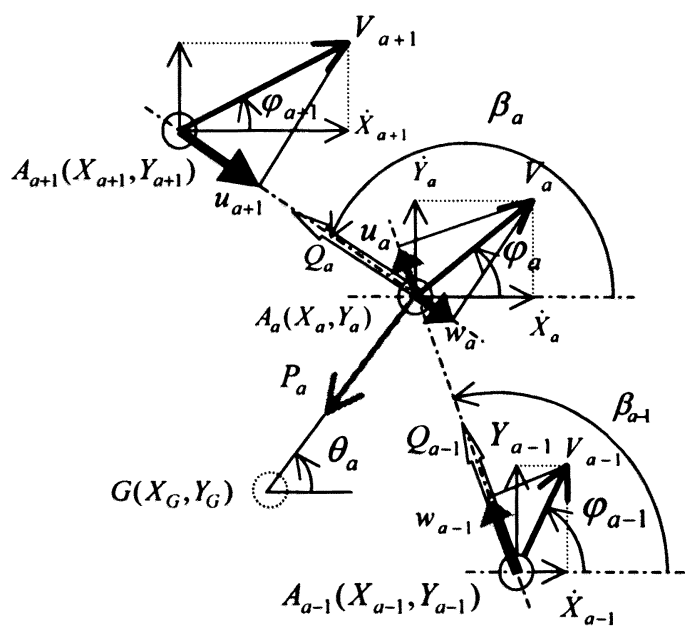

Figure 7 Free body diagram of $A_{a}, A_{a-1}$ and $A_{a+1}$

Table 2 Initial condition

\begin{tabular}{|c|r|r|r|}
\hline Condition & (a) & \multicolumn{1}{|c|}{ (b) } & (c) \\
\hline Horizontal velocity (m/s) & 1.7 & 1.0 & 1.0 \\
\hline Vertical velocity (m/s) & -2.3 & -1.0 & -1.0 \\
\hline Rotational velocity (rps) & -21.7 & 10.0 & 30.0 \\
\hline
\end{tabular}




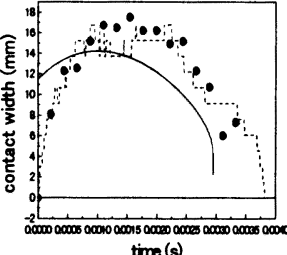

(a)Contact width

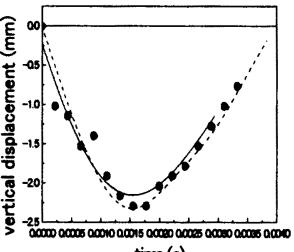

(c) Vertical expansion and contraction

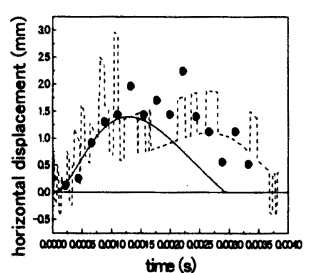

(b)Horizontal expansion and contraction

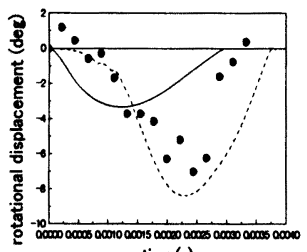

(d)Rotational expansion and contraction
- experimental numerical (simple model) numerical $(\mathrm{F}=90)$

Figure 8 Comparison of numerical results with experimental ones during contact

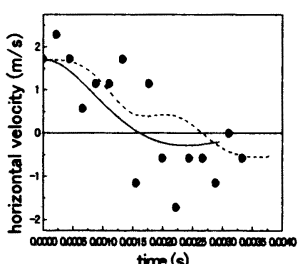

(a)Horizontal velocity

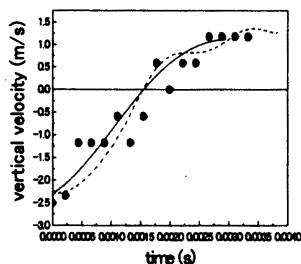

(b) Vertical velocity

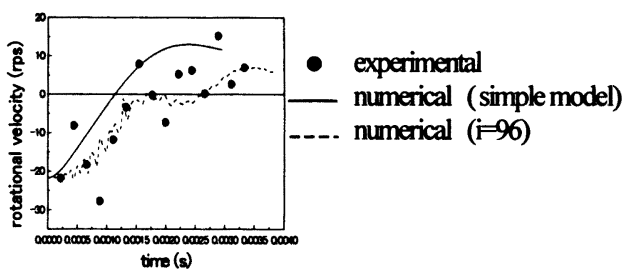

(c)Rotational velocity

Figure 9 Comparison of numerical results of velocity with experimental ones during contact

示していることから，この方向の剛性值や减衰係数值 はほぼ妥当といえる。
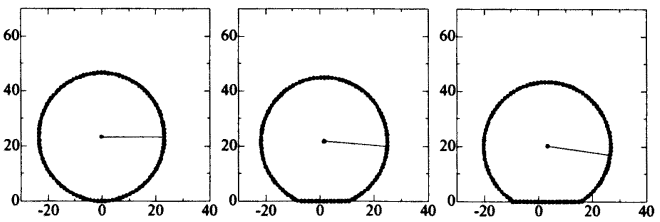

(a) $t=0$ (Start)

(b) $t=0.00043$
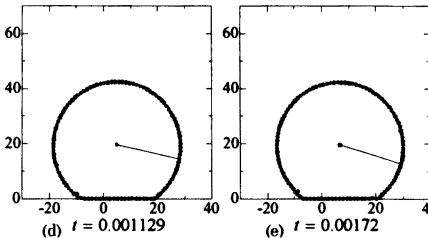

(c) $t=0.00086$
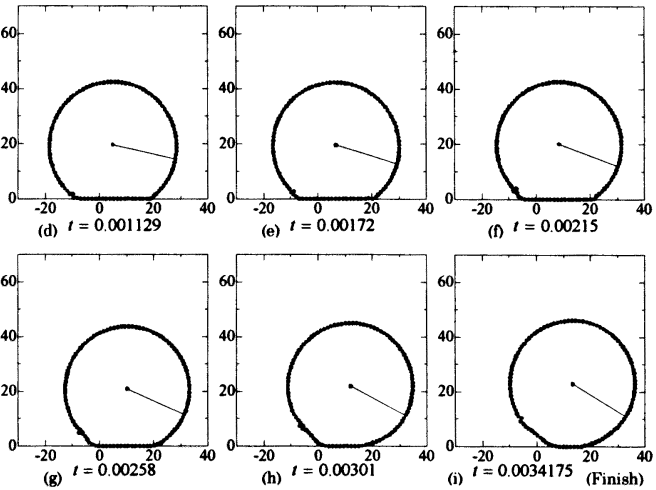

Figure 10 Mode shapes of ball with condtion in Table 3

図 10 は多質点モデルによる球の衝突時における $4.3 \times 10^{-3}(\mathrm{~s})$ ごとの変形状態を示したもので, 直線 は質点 $G$ と質点 $A_{0}$ を結んだものである. 時間経過に つれて接触幅, 質点 $G$ や最上部の沈みが増加してゆ き, 衝突開始後 $11.29 \times 10^{-4} \sim 17.20 \times 10^{-4}$ (s)附近で それらの值が最大となり, 以後それらが回復していく 様子や, 円周方向の局所的な回転方向伸縮が生じてい る様子もわかる.

図 11 は表 $2(\mathrm{~b}),(\mathrm{c})$ の初期条件のもとに多質点モ デルで計算した球のモードを示したものである. 図に おいて質点 $G$ と直線で結ばれた外周質点は $A_{0}$ と初期 状態で地面と接触している $A_{72}$ であり, 時間間隔は $\Delta t=8.0 \times 10^{-4}(\mathrm{~s})$ である. 図 11(a)では外周質点 $A_{72}$ の位置は時々刻々変化しておりすべり運動が発生して いる様子が, 一方図 $11(\mathrm{~b}) て ゙ は A_{72}$ の位置はあまり変 化せず転がり運動が生じている様子がわかる。

4.2 行突前後の速度に関する比较 図 12 は初期条 件（水平方向速度，回転方向速度）を種々に変えた場 合の衝突前後における速度の関係を示したもので，図 中における直線は最小二乗法により求めた近似直線で ある.

図 12(a)は衝突前の回転方向速度を基準とした衝突 前後の水平方向速度の関係である. 実験值, 簡易モデ ル，多質点モデルによる計算値はほぼ同領域に分布し ており, 衝突後の水平方向速度は衝突前の水平方向速 度と回転方向速度に依存していることがわかる。 


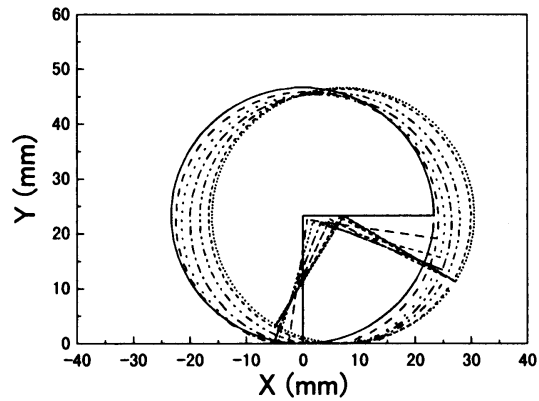

(a) Slipping motion [condition (b)]

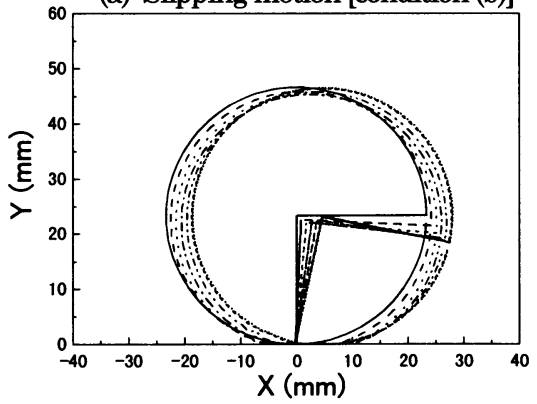

(b) Rotating motion [condition (c)]

Figure 11 Mode for the condition in Table2(b),(c)

図 12(b)は, 衝突前の水平方向速度を基準とした衝 突前後の回転速度の関係である. 実験結果の近似直線 に比べ，簡易モデルの近似線の傾きは大きくずれてい る. 衝突後の回転速度は複雑に変化するため, これを 精度よく表現するためには簡易モデルでは無理がある ことがわかる.

図 12(c)は, 衝突前後の垂直方向の速度の関係で, 実験結果と多質点モデルの結果はよく一致している. これらに比べ簡易モデルの結果は小さめな值となって いるが, 近似直線の傾きは概ね一致している. この傾 きは跳ね返り係数を示しており, 約 0.8 である.

\section{3 挙動全体の比較 本節ではある条件下で生じ} る繰り返し跳㸚返り挙動について検討する. 表 3 中 (a), (b)の衝突直前の条件下における球の重心位置の 軌跡をそれぞれ図 13(a)，(b)に示寸。

図 13(a)に示す実験結果では, 並進（水平）方向に 対して逆回転で衝突し, 並進方向に大きく減速して跳 ね上がり, 次の衝突後には大きく前進するという特徴 がある.このためには 1 度目の衝突後の回転方向が順 回転に変化し, これが 2 度目の衝突後の並進方向速度 を大きくする役割を果たしていると考えられる.この

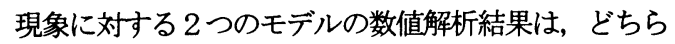

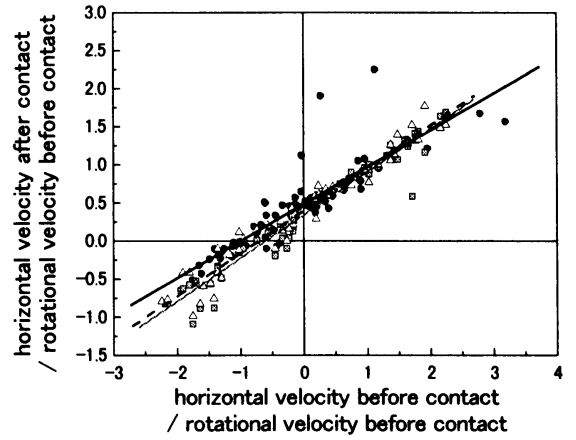

(a) Horizontal velocity after contact

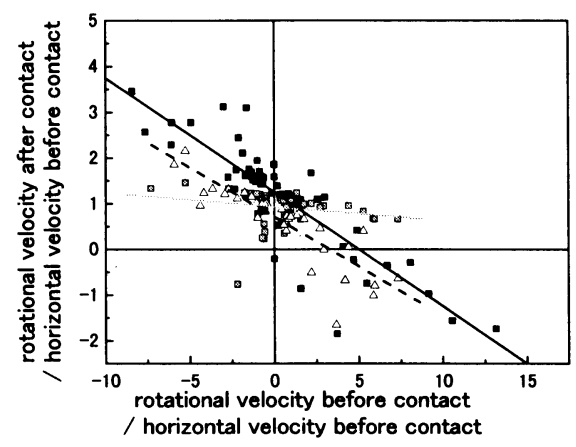

(b) Rotarional velocity after contact

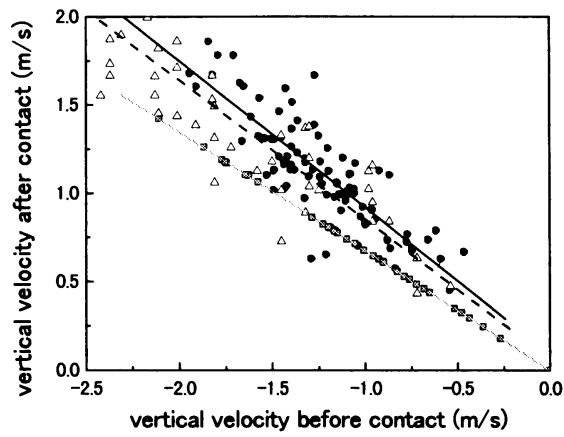

(c) Vertical velocity after contact

- experimental

- numerical (simple model)

$\Delta$ numerical $(i=9)$

- linear approximation of experimental results

- linear approximation of numerical results

---. linear approximation of numerical results

Figure .12 Relationship of velocity between before and after collison

も並進方向速度の减速, 加速といった特徵が表現でき ているものの 2 回目の衝突以降の挙動には定量的な差 が生じた.

一方，図 13(b)は前述の図 3 と同種の挙動であり， 
Table 3 Initial condition

\begin{tabular}{|l|r|r|}
\hline & \multicolumn{1}{|c|}{ (a) } & \multicolumn{1}{|c|}{ (b) } \\
\hline Horizontal position $(\mathrm{m})$ & 0.0726 & 0.1955 \\
Height $(\mathrm{m})$ & 0.1051 & 0.44574 \\
Horizontal velocity $(\mathrm{m} / \mathrm{s})$ & -2.42 & -1.62 \\
Vertical velocity $(\mathrm{m} / \mathrm{s})$ & -3.2 & -2.61 \\
Rotational velocity (rps) & 20.7 & 22.5 \\
\hline
\end{tabular}

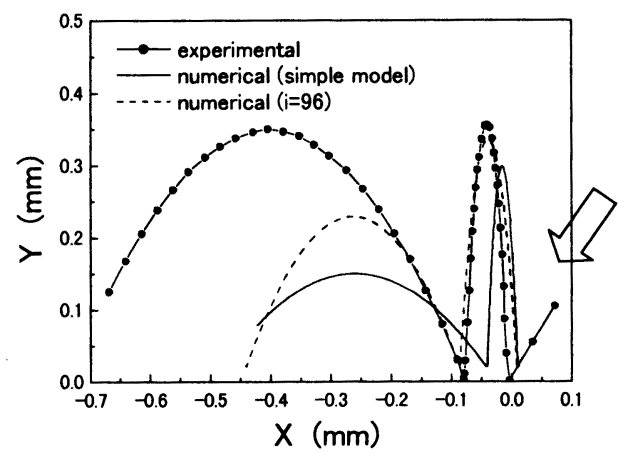

(a)Forward motion

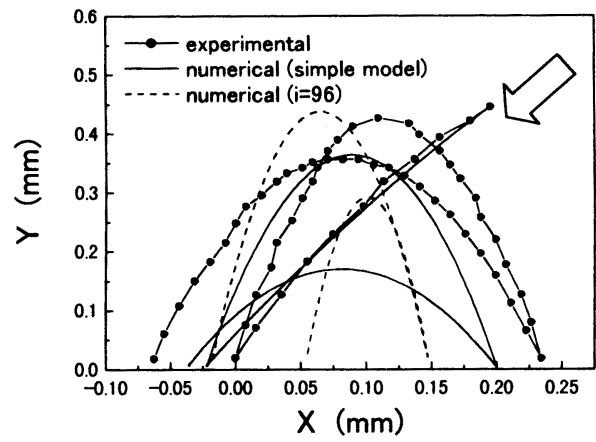

(b) Backword and forward motion

Figure 13 Behavior of a ball during multiple collisons

逆回転で衝突し，その衝突後に順回転で後進し，次の 衝突後にまた再び逆回転で前進するという, 弾性に富 む物体特有の挙動である. 2 つのモデルによる数值解 析結果はこの特徴を捉えてはいるものの定量的な一致 は得られなかった。

\section{5. 結 論}

本論文では, 回転弾性球の衝突時平面内挙動を解 析するためのモデルとして簡易モデルと多質点モデル を提案し，定式化を行った．簡易モデルは，回転球が 衝突する際, 局所的な回転方向伸縮が系の運動に支配 的に影響を与えることを実験結果から考察して得られ たものであり，重心質量による並進運動に加えて，接
触部に配置された質量により回転運動も表現できる. 一方多質点モデルは, 球の各方向の変形を詳細に扱う ことによって, 例えば回転方向伸縮量の場合, その歪 み分布を外周上で表現できるなど, 高精度な解析を可 能にする.

実験結果とこれらのモデルによる数值解析結果の 比較より得られた結果を要約すると

(1) 衝突時の局所変形の定性的な傾向を知るためには 簡易モデルで十分である.

（2）多質点モデルは球の衝突時の挙動を支配する因子 と考えられる局所変形すなわち水平, 垂直, 回 転の各方向伸縮を表現でき, 計算結果は実験值 と定性的，定量的に良好な一致を示す。

（3）簡易モデル，多質点モデルによれば弾性球に特有 な繰り返し跳ね返り挙動を表現できる。

（4）多質点モデルによれば運動中の弾性体の変形状態 を知ることができる.

以上のように, 簡易モデル, 多質点モデル共に, こ こで扱った回転弾性球の衝突時挙動を解析するモデル として実用上有効であることが示された。 一方, 複数 回の繰り返し衝突を含む運動については, 衝突回を重 ねるごとに，定量的な表現が困難となった。 この改善 のためには, 最適な諸定数の設定方法, さらに接触中 のエネルギ消費などに着目した詳細な接触モデルの構 築，また実験における衝突開始点と終了点の正確な判 定方法の確立等が必要と考えられる。

\section{参考文献}

(1) 例えば, R. M. Brach, "Rigid Body Collisons" , J. of Applied Mechanics, Vol.56,(1989), pp133-138.

(2) 例えば, C. Glocker and F. Pfeiffer, "Dynamical systems with unilateral contacts", Nonlinear Dynamics, Vol.3,(1992), pp245-259.

（3）例えば，河本，他 3 名, 回転槽内における 2 物体 群の挙動解析，機論(c)，67-661(2001)，2981-2988。

（4）例えば, V. D. Barger and M. G. 01sson, Classical Mechanics-A Modern Perspective, 培風 館, (1973), 164-168.

（5）例えば, 本江, 他 3 名, ゴルフボール衝突特性

(衝突モデルの妥当性)，日本機械学会機械力学 計測制御部門講演会 講演論文集（2003），CD-ROM.

（6）例えば，山本，他 2 名, 階層型接触モデルに関す る動力学的考察, 第 52 回理論応用力学講演会講 演論文集（2003），563-564.

（7）粉体工学会, 粉体シミュレーション入門, 産業図 書, (1998)， 33. 